\title{
GENDER, POVERTY, AND DOMESTIC VIOLENCE IN RURAL BENGAL: THE JEEVIKA DEVELOPMENT SOCIETY'S JOURNEY THROUGH WOMEN'S RIGHTS-BASED MICROCREDIT PROGRAMS
}

\section{Nilanjana Sengupta and Dolon Ganguly}

Nilanjana Sengupta is Assistant Professor, School of Women's Studies, Jadavpur University, Kolkata, India, and may be reached at nilanjana.seng@gmail.com. Dolon Ganguly is Executive Director, Jeevika Development Society, West Bengal, India, and may be reached at dolonganguly@gmail.com. The authors acknowledge the academic and administrative support provided by Amit Bhattacharya, a senior management staff member at Jeevika Development Society. The authors also are deeply grateful for field work and other support provided by Indrani Chakraborty and Mousumi Sarkar, senior management staff at Jeevika, as well as assistance by Somdutta Mukherjee, Ph.D Scholar, School of Women's Studies, Jadavpur University, Kolkata.

\section{Abstract}

To understand the nature of the links among gender, poverty, and violence in specific sociocultural contexts, this article unravels a complex web of interactions among the Jeevika Development Society, the communities in which its members live, and women's individual initiatives. It also examines the process by which ruptures are made in these links through women's active participation in the Society. The article asks whether economic outcomes facilitated by the organization have any impact, or are impacted upon, by gender relations at home, which manifest themselves through different forms of violence. It further explores whether dimensions of participation that are more social than economic, such as voluntary work with antiviolence forums as well as positions of leadership in the Society, create possibilities of empowerment that are stronger and more direct than the possibilities that may emerge through economic gains alone.

$\mathrm{T}$ hird world feminist writing since the 1970s, especially in India, has, on the one hand, located women's poverty within the multiple axes of class, caste, and gender in postcolonial societies and, on the other hand, refuted the dominant Western feminist projection of women in these contexts as victims of violence and subordination. Third world feminist writing focused on recovering women's voices, roles, and agencies in art, literature, political, and economic life. In the post-globalization phase, specifically after the onset of Structural Adjustment Programs (SAP) in 1991, much has been written on the adverse effects of economic reforms on poor and vulnerable populations, especially of women. ${ }^{1}$ In the midst of global discontent with neoliberal reforms, policymakers, including international development organizations such as the World Bank, "discovered" women as target groups of positive social and economic intervention owing to their historical roles in managing families in poverty and their potential to contribute to economic development. ${ }^{2}$

As from the 1970s, feminist writing had been exploring the relationship between women and development highlighting both the exclusion of women from processes of development as well as the need to critique models of development based on exploitative modes of production. Such writing also gave rise to issues of women's agency and empowerment encompassing multiple dimensions of women's attainment that needed to be situated within the nexus of patriarchy, state, and capital. The empowerment discourse, which resurged in policy literature of national governments as well as international organizations in the 1990s and thereafter, was a much altered version of this. It individuated the question of women's empowerment from its larger structural connections with state and capital, focused more on individual enterprise than on collective action, and in many cases also reduced the complex dynamics of empowerment to narrow economistic dimensions that would have trickle-down effects on social dimensions of wellbeing. ${ }^{3}$

It is around the same time that microfinance programs for women became popular the world over, inspired by the success of institutions such as the Grameen Bank of Bangladesh. Microfinance programs required minimum state financial investment and could be built on a model of commercial viability where the onus of microenterprise development as a poverty alleviation tool rested on individual loan beneficiaries. At one level, this was a strategy of banking the unbankable, owing to joint liability and peer monitoring, as against traditional methods of collateral deposit. At another level, by targeting women one could have continuous access to a captive 
population (moreover, with low mobility) who used small doses of loans for building or expanding small enterprises, traditionally identified as womanly, and who could also be counted on to prioritize family welfare over irregular personal expenditures.

Only much later was it realized that poor people need loans for a variety of purposes, including consumption smoothing and crisis management. Many organizations then brought these categories within their ambit. Even in this case, poor people had the option of formal sources of credit, based on market rates of interest, instead of depending solely on informal moneylenders. It was also claimed that by placing financial resources, however small, in the hands of women, microcredit programs would enhance women's economic self-sufficiency leading to empowerment. The Indian government took active part in microfinance schemes first by making it a primary plank of its anti-poverty program (Swarnajayanti Grameen Swarozgar Yojna) and through the aegis of the National Bank for Agriculture and Rural Development (NABARD), which linked the vast network of commercial and rural banks to women's self-help groups (SHGs). The government sought out various nongovernemental organizations (NGOs) as allies in this process. NGOs engaged in microcredit delivery both independently and in collaboration with the government.

Currently, three principal models of microcredit operate in the Indian context. First are government-run or governmentsupported programs with a small element of subsidy in credit or interest. Second is commercial microfinance, operating through nonbank financial intermediaries, which are for-profit organizations involved in minimalist credit delivery. And third are NGOs, which offer credit-plus programs. These combine a mix of microfinance with other capacity-building programs, many of which are funded by national and international development institutions. Jeevika Development Society (henceforth Jeevika) broadly falls within the third category. A small number of programs have invested in building community-based organizations, and Jeevika has been one of these few.

The different SHGs promoted by Jeevika are now federated into a community-run organization named Swayamsampurna (a Bengali word meaning self-sufficient), which deals with loans, savings, and other financial services. Jeevika continues to guide the Swayamsampurna but focuses more on capacitybuilding and other initiatives aimed at generating awareness, creating employment opportunities, and challenging violence or discrimination faced by women.

This article contextualizes the issue of women's empowerment in this historical trajectory of understanding the women and development question. In the later part of the
To understand the nature of the links among gender, poverty, and violence in specific sociocultural contexts, this article unravels a complex web of interactions among the Jeevika Development Society, the communities in which its members live, and women's individual initiatives. It also examines the process by which ruptures are made in these links through women's active participation in the Society. The article asks whether economic outcomes facilitated by the Society have any impact, or are impacted upon, by gender relations at home which manifest themselves through different forms of violence. It further explores whether dimensions of participation that are more social than economic, such as voluntary work with anti-violence forums as well as positions of leadership in the Society, create possibilities of empowerment that are stronger and more direct than the possibilities that may emerge through economic gains alone.

1990s, when women emerged through policy discourse as a major target group for development, India, like many other "third world" nations experienced a sudden rise in the number of microfinance programs and institutions. Microfinance was beginning to be seen as a "magic bullet" that would transform lives and bring about social and economic empowerment of women and their families. ${ }^{4} \mathrm{~A}$ vast critical literature exists today to show that this relationship between microfinance and empowerment is tenuous and nonlinear. ${ }^{5}$ This article unravels a complex web of interactions between the Society, i.e., Jeevika, the communities in which its members live, and women's individual initiatives to understand the nature of the links among gender, poverty, and violence in specific sociocultural contexts. It also examines the process by which ruptures are made in these links through women's active participation in Jeevika. The article asks whether economic outcomes facilitated by the Society have any impact, or are impacted upon, by gender relations at home, which manifest themselves through different forms of violence. It further explores whether dimensions of participation that are more social than economic, such as voluntary work with antiviolence forums as well as positions of leadership in the Society, create possibilities of empowerment that are stronger and more direct than the possibilities that may emerge through economic gains alone.

We argue that while direct economic wellbeing and control are important pathways of empowerment, they are neither enough nor absolutely necessary to challenge patriarchal dominance or violence. Violence, understood in the broad spaces of the emotional, physical, sexual, and material, and embedded within patriarchal heterosexual families, can be combated by a combination of economic self-sufficiency, a sense of contribution, dignity, and confidence, and most importantly by a sense of association with a support group that 
can be counted upon as a concrete alternative for material and ideological struggles. In short, when women's fallback position increases in terms of social and economic alternatives, so does their ability to negotiate the everyday violence of their lives, be it through open resistance or subversion. An organization like Jeevika facilitates this rich mix of social, economic, and ideological support that enables some if not all women to envision a different life for themselves.

\section{Methodology}

The article uses the standpoints of both the insider and outsider. One of its authors has been leading the Society for more than a decade; the other has been independently associated with the Society as a researcher-activist for more than five years. While this introduces a certain familiarity and power between the researchers and the researched, it also enables us to draw upon a rich host of experiences and previous research as well as facilitating a "talking point."

For the purpose of this article, the authors conducted 22 individual, semi-structured interviews with four categories of women. The first were members in positions of leadership in Swayamsampurna or its allied bodies such as Alor Disha (a women's group working on the issue of violence against women).In the second category were members who have taken production loans from Swayamsampurna to either start or expand their own microenterprises. The third category consists of members who have taken production loans for their husband's or family's business. The fourth category includes survivors of violence who have sought active support of Alor Disha in dealing with their cases of violence.

The reason for this purposive sampling was to bring to the fore links between economic participation or leadership and gender relations at home. Although many loans are taken for purposes other than production, production loans, whether for self or family, enable a closer scrutiny of ownership of business, participation in the business, and control over income streams at home and in the business. Positions of leadership have interesting noneconomic dimensions of empowerment, including dignity and confidence and a sense of social contribution. Narratives of survivors of violence tried to link the debilitating aspects of economic and social violence and the role organizations like Jeevika play in creating a platform for alternative modes of survival.

The sample is not representative and indicates some of the ways in which the multiple axes of gender, poverty, and violence can be interpreted through life stories of women surviving in such contexts. Additionally, the article also draws on the personal experiences of the authors and the rich host of information and data existing within the Society.
Situating Jeevika's women's rights-based approach in the empowerment discourse

Founded in 1990, Jeevika was registered as a Society (a charitable, not-for-profit organization) in 1994 to provide women access to financial resources and livelihood opportunities. Jeevika's micro-savings and credit program and its income generation program were launched in 1990. Right from inception, one of the stated goals of Jeevika was to build transparent, self-sustaining, and democratic institutions, and to transfer their ownership to the rural women. Starting with 90 women in three villages, By 2008, Jeevika's microfinance program evolved into a 500-group financial federation — called Swayamsampurna. Registered as a Mutual Benefit Trust in 2010 , the federation is owned and managed by rural women. At the time of writing, Swayamsampurna works with more than 9,000 women in 704 SHGs across 51 villages that are spread across three blocks in the district of South 24 Parganas in West Bengal, India. Of these villages, some are located fairly close to Kolkata while some are very remote. ${ }^{6}$

\section{Women's practical and strategic needs}

Following Caroline Moser, we differentiate between practical and strategic needs of women, the former responding to certain, immediate needs for survival and the latter relating to change in the structure and nature of gender relations. Microcredit, whether taken for consumption, emergency, or microenterprise, often responds to a practical need for human survival. Whether this practical need can be converted to address a strategic gender need depends largely on processes of negotiation and bargaining stimulated by practical need as well as Swayamsampurna's overall engagement with the member beyond the immediate need.

Moser discusses various approaches to the woman in development question in which the equity approach appears effective since it has the ability to take into account women's practical as well as strategic needs. Most microfinance organizations, however, follow an efficiency approach to the women in development question. Such approaches, as condoned by organizations like the USAID, the World Bank, and the OECD, have often shifted the emphasis, “... away from women and toward development on the assumption that increased economic participation for 'third world' women is automatically linked with increased equity." Given that productivity and efficiency are two main approaches of Structural Adjustment Programs, national governmentsincluding India's - have readily adopted this approach, focusing on microfinancial services with, at best, additional doses of vocational training, while steering clear of any conscious challenging of gender relations at home. ${ }^{7}$ 
One scholar argues that this toned-down version of the equity approach arises out of the reluctance of development agencies to interfere with gender relations constructed in specific societies. In a Bangladeshi study, for instance, it was found that repayment demands along with contentions over control of the loan have led to increased violence against women. Another study, a survey on urban microfinance in Delhi, India, observes that institutional staff advise women to comply with family wishes so that such institutions do not lose legitimacy in the community. Thus, while women work more to support families, their rights do not necessarily increase. This resonates in some feminization of poverty studies when scholars point out that in recent times "third world" women are experiencing a rise in responsibility and labor time without concomitant rise in rights and entitlements. ${ }^{8}$

Jeevika is exceptional in this regard as it consciously tries to establish links between credit and rights. Using group formation around microfinance as an entry point, Jeevika simultaneously engages in awareness generation and political mobilization beyond it. Day-long training events attended by all groups discuss not only financial administration and management but also women's economic and social rights. In addtion, three-day training workshops are held throughout the year, in locations outside the village, in which issues of women's rights, violence, and hurdles to entrepreneurship are discussed. Group meetings, held once a month, typically discuss social issues along with monetary transactions and also provide information about financial services, programs and workshops on gender rights, and vocational training available for members.

A bottom-up approach and the importance accorded to participatory development is clear from the fact that nearly all members are aware of the changes that have occurred through ownership transfer from Jeevika to Swayamsampurna. During the formative phase of Swayamsampurna, a large part of the new operational policy was based on discussions with ordinary members and their expressed needs. (Incidentally, the policy of not requiring a male guarantor for Swayamsampurna loans was inspired by the suggestions of ordinary group members who felt that it would violate their independence to use loans without the knowledge of their husbands.)

As from the late 1990s, Jeevika identified sexual control, violence, and restrictions on women's mobility as major deterrents of women's economic and social wellbeing. Keeping this in mind, community-initiated rallies, theater performances (Jeevika has its own theater repertory consisting of members of the community), and other events were organized to annually commemorate the International Women's Day and the International Fortnight Protesting Violence against Women and
A Bangladeshi study found that repayment demands along with contention over control of loans have led to increased violence against women. Another study-a survey of urban microfinance in Delhi, India-observes that institutional staff advise women to comply with family wishes so that the institution of family does not lose legitimacy in the community. Thus, while women work more to support families, their rights do not necessarily increase. Jeevika is exceptional in this regard as it consciously tries to establish links between credit and rights.

Girls. This was followed by the launch of Rapid Response Training (RRT) in 2002, which is a set of training programs that equip women with hands-on skill to respond to acts of violence against women and girls as and when they occur in their lives or in their neighborhood. Out of the RRT grew a voluntary forum, called Alor Disha. Since its inception, Alor Disha has been dealing with more than 150 cases of violence each year. Jeevika also runs an income generation program, which not only conducts vocational training (including knowledge of computers) but also offers opportunities of working in production units such as soft toy-making and tailoring.

For a long time, Jeevika insisted on training and production at its main office so as to create an incentive for increased mobility. However, it was felt that reproductive responsibilities and sexual control tie women down in such ways that they are unable to respond to this incentive. In view of this, Jeevika has recently started village-based income generation training and production units with the hope that once women start production, incomes generated would enable them to bargain for greater mobility at a later stage.

\section{Community leadership}

Perhaps the most important contribution of Jeevika has been in developing community leadership for members to manage and own their own institution. Thus, Swayamsampurna is run by a 12 member Board of Trustees who act as a Board of Directors, and 11 of whom are community members elected through the General Body (comprising all members of Swayamsampurna). The remaining Director is an official of Jeevika nominated by the General Body. The vast network of group meetings, collections of savings, and loan installments, as well as loan disbursement, is done mainly by loan officers, who are members of the community appointed by Swayamsampurna through a process of examination. Swayamsampurna support staff provide additional assistance to the loan officers. The process of loan screening and sanction is done by the Board of Directors with input from the loan officers. Swayamsampurna now independently applies for loans from banks and other 
institutions as well as depending on the financial return on its loans to cover its running costs. The savings are collected and deposited in area-based bank accounts of Swayamsampurna. ${ }^{9}$

On the question of empowerment, third world feminists have continuously emphasized increased capacities of selfreliance and internal strength rather than power over people. Empowerment is identified as the right to determine life choices and to influence the direction of change through the ability to command both material and nonmaterial resources. One author writes that empowerment cannot be bestowed by a third party; it has to be claimed by the disempowered. At best, development agencies can facilitate conditions for women to empower themselves. ${ }^{10}$

Investment in community leadership that enables women to decide and act on behalf of an organization creates such capabilities which may have a direct or indirect effect on the realm of choices in women's personal lives. Jeevika's interventions in the form of leadership building, consciousness raising, forums for creative expression, and campaigns against violence integrate the service delivery model of microfinance with the enhancement of capacities for self-reliance, strength, and confidence. Thus there is a deliberate attempt to create adequate support networks and strategies that have possibilities to transform economic transactions into a socio-political struggle for re(en)visioning individual lives.

To what extent do these institutional processes remove constraints in the direction desired by women in terms of their own choices and wellbeing? Do these shifts redefine what has been called the (im)possible, the (im)probable, the natural, the normal, or what counts as a problem? In other words, does association with Jeevika give rise to processes by which "women redefine and extend what is possible for them to be and do in situations where they have been restricted, compared to men, from being and doing"? The following discussion tries to understand these processes through empirical research. ${ }^{11}$

\section{Stories of struggle, survival, and change}

Bhabani Sardar, ${ }^{12}$ Secretary, Swayamsampurna, remembers her impetus to join Jeevika about 12 years ago: "I did not initially think about loans. Savings was one issue but what attracted me most was that some of the women used to go out for one day trainings ... I felt this would give me a scope to move out of the house. For ten to fifteen years after marriage, I could not go anywhere. I had been converted into an inert object of labour. I used to feel claustrophobic. It was as if a dam was waiting to burst. There was a huge pressure building inside me. I felt that perhaps my association with Jeevika would give me an opportunity to step out."13 Many women, especially women in leadership positions, echo Bhabani's sentiment. Most of them, including members of Alor Disha, are also members of Swayamsampurna and have taken loans for their own or their family's business. But the main driving force in their lives seems to be the support group and voluntary work that they are part of. Victims of domestic violence during some part of their lives, such women have used the opportunity given by Jeevika to transcend narrowly defined, family-bound lives and obtain ideological and material tools to justify resistance and change.

Ranu Mondol, an activist with Alor Disha, who walked out on her husband after extreme violence, seems to have outgrown the need for self-pity: "Now I feel that what happened to me was probably for the best. Otherwise, as a married woman in exploitative conditions, I would never have reached so far. My fulfillment in life comes from helping so many women in distress. This has given me a recognition and purpose which otherwise I would never have reached." As a full-time activist, Ranu appears on television shows, is invited to many workshops by other organizations, including the government, is consulted by the village level governing body, the Panchayat, in cases of violence, has traveled widely, and is familiar with the law enforcement and judicial systems. The fight for justice through the intervention of Alor Disha has taken Ranu, and many like her, far beyond the concerns of their own cases to connecting with a larger social cause. This also serves to make the personal, political.

A loan officer, Sipra Biswas, another victim of violence and continuous sexual control by her husband, says that after seeing the condition of women in the villages she visited, she realized that this was not a problem that was only her destiny. In fact she was better off than many other women in similar conditions because she had at least been able to step out. The job with Swayamsampurna has not only given her a steady income with which to justify her mobility to her husband, but has brought her in contact with a large network of colleagues who help her strategize ways of coping with violence and who give her the moral support to question domination in her life.

The narratives throw up the fact that activist work as well as income generating work give some women a purpose in life beyond the family and some others a way to negotiate restrictions imposed by the family. Those associated with loans and income generation alone may not have the kind of articulation of rights and change as those more actively associated with rights-based programs, but they nevertheless show a degree of control over their lives which participation in economic activities have made possible. Thus, stories of joint business where women are equal participants in labor effort and financial management arise in two cases: first through cooperative families where there is an absence of violence and active support of the husband in jointly advancing the welfare 
of the family and, second, in cases where the husband is indifferent or incompetent to provide for the family's need on his sole initiative.

\section{Joint control of business in cooperative families}

Sumana Sardar, Pramila Naskar, and Reba Naskar fall within the first category. Reba and her husband sell phuchka (a type of snack) in separate areas of a neighborhood. They jointly prepare the material and travel to their roadside stalls in the same van, returning home together, after the day's marketing. The motivation to work jointly came from their desire to augment income and retain two physical spaces for sale of their snack. Although her husband is careful and does not squander money, Reba is mainly in charge of monetary decisions. Her husband has a bank account because of his earlier MGNERGS (Mahatma Gandhi National Rural Employment Guarantee Scheme) work but now insists on Reba becoming a joint account holder.

Sumana took loans from Swayamsampurna for her family's pig farm business. Initially, they had a poultry farm which suffered huge losses due to an attack of Bird Flu disease. At that time, her husband was looking after this business alone. The loss of poultry due to Bird Flu led to huge debt in her husband's name. Faced with dire poverty, Sumana started tailoring work while her husband worked as a daily wage laborer and, bit by bit, repaid the debts. It was a tale of joint endeavor at making ends meet. Perhaps this cooperation won his confidence and, at a later stage, when they gathered enough money to start a pig farm, she was counted as an ally. In charge of cleaning the pigs, caring for the new-born pigs, and administering medicines, Sumana leaves sales management and financial dealings to her husband. However, she shows an awareness of prices and dealers and the places from which medicines and food are procured for the pigs. At one point, when her husband fell ill, Sumana managed the whole business on her own. Her husband seems to trust her with budgets and money and has even bought land in her name.

Pramila Naskar took loans from Swayamsampurna for her husband's garment business, which has expanded from a home-based affair to a full-fledged shop. She herself binds bidis in the morning and sits in her husband's shop in the evening. A large part of their business runs on credit advance and her husband is in charge of collecting installments while she looks after the sales. She herself travels to wholesale dealers in distant locations, accompanied or unaccompanied by male family members, to procure garments of her choice. It is quite notable that she has exact knowledge about the business's turnover, the existing amount of advances in the market, and the exact number of customers. Most decisions, by her account, are jointly taken by her and her husband and the money from the business is kept with her.

Strategic control of business in noncooperative families

Deepa Sardar falls within the second category. Faced with violence and an alcoholic husband, Deepa took over the running of a tea and snack shop in order that her family may survive. She does the major work from cooking to procurement to general management of the shop, although her husband sits in the shop and controls the cash. Deepa won her husband's confidence by entrusting the management of finances to him and by giving him the sense of being the actual owner despite the fact that she is the one who actually puts her brains and labor to it. Deepa says: "It's important for a man to be there. It's difficult for a woman alone in the shop ... all types of customers come ... so a man is needed. People will be afraid to say anything if he is there. He sits in the shop but I do all the work from cooking to washing. He says that if he is there, there will be fewer problems because the customers know that the shop owner is here." At the beginning of the interview, she says that she hands the finances to her husband because she is not careful with money. But at a later stage of the interview, she mentions: "I should not demean him by keeping the money with me. He gives me what I need, so why should I keep the money? It's the same whether it is with me or him." Perhaps her apparent acceptance of his superiority has given her the scope to earn a living for the family and counter the violence she faced by proving her commitment both to the family's economic wellbeing while conforming to the ideology of male superiority.

\section{Relinquishing control of business to the male}

In other instances of loans taken for a family business, the woman does not seem to have much of a role beyond being the vehicle for the loan. Two distinct patterns emerge in these cases. First, there are cases where the woman has intrinsic faith in the male provider model and is satisfied by the benevolence of her husband. Second, there are cases where the woman has suffered so much violence that she has lost interest in any cooperative structure of family business.

Sarika Naskar and Sulata Adhikary belong to the first category. Sarika took a loan from Swayamsampurna for her husband after his employer, a garment manufacturer, instituted a factory lock-out. She herself manages livestock and poultry and helps him in home-based sales, as per his instructions. The entire business, financial dealings, and control are in his hands. Sarika, however, does not have any qualms about this. She says, "My husband has always helped me and even my natal family, be it my sister's marriage or my mother's illness. My 
mother could not give the promised dowry but I have never been harassed about this. So I realised that these people are really very good. My husband is not like other men. So why should I not listen to him? Why should I do anything on my own?" It would appear that violence and material deprivation are normalized in marital relations to such an extent that any exception to the rule make women grateful to the point of servitude and anxious to conform to expected norms.

The same is the story of Sulata Adhikary who has taken loans for her husband's auto rickshaw lease and seems extremely grateful for finding a husband who takes care of her material and health needs. Her gratitude overflows when she mentions that her husband has bought a house in her name, reposing trust in the fact that there is no difference in whether the title deed is in her name or his since they are to spend their lives together. To convince the interviewers of her husband's affection and care she mentions how her husband appointed a paid domestic worker at a time she was ill and bed-ridden. Her gratitude has paid off in the fact that over the years her husband entrusts money to her hands. Sulata immediately dismisses the relevance of Jeevika's rights-based program in her own life by stating that her life story does not require any such arbitration. One wonders at her aggressive denial of violence or violation of rights, whether a large part of this is a strategy to ensure continued good behavior and benevolence of her husband. Could any questioning of gendered norms, which she is careful to avoid, result in a breakdown of this benevolence?

Sikha Das falls within the second category. She takes no interest in her husband's business primarily because she is disillusioned about any cooperative endeavor in the family. A member also of Alor Barta (a forum of Jeevika for preventing child marriage), she has taken many loans for her husband's hotel business. Herself a victim of child marriage and having faced extreme sexual and physical violence at her marital home, she hands the loans to her husband and takes no further interest. The financial turnover from the business is good and now, after many years of violent marriage, she has some measure of peace and material wellbeing. Sikha leaves finances to her husband and finds her sense of self-worth mainly through her activist work with Alor Barta. The small stipend she earns through this is hers to spend. Perhaps her endurance of violence over the years and the fact that she does not contest her husband's financial control earns her the peace to do activist work. However, the activist work has given her an insight and perspective that enables her to critique and protest her previous suffering. She says: "If I had the knowledge and confidence that I have gained through Alor Barta earlier, I would have taught him a lesson at that time. Now I answer him back in everything. One day he told me, you have learnt to speak a lot. I retorted saying that of course I have, there would be a difference in the way a fourteen year old girl talks and a woman of my age talks. I told him that as a young girl I had accepted everything he asked me to. Now it can no longer be like that."

\section{Financial control within normative boundaries}

It is interesting that even in cases where women take an active part in their husband's business and are also largely in control of the finances, there is a sense of dependence and obligation. Despite having a joint account from which she can withdraw money as required, Sumana says that she does not spend money in large amounts without her husband's knowledge: "Since I do not earn the money myself, I cannot give any loan to the members of my natal family without the knowledge of my husband. I cannot take such risk. If I earned on my own then I could have taken a risk and given that money from my own income." She plans to revive her tailoring business once they have enough money to keep hired labor for looking after the pig farm.

Does independent production/business by women then give them a larger measure of control and enable a questioning of gendered norms of wifehood and motherhood? Most women who run successful business on their own started production activities following widowhood, desertion, or the incapacity of husbands to take economic responsibility. For instance, Sarbani Mondol started her saree and garments business about 25 years ago when her husband was ill and unable to take care of the family. Initially, she worked as a paid domestic worker and soon realized that a business would give her greater income and self-reliance. She herself traveled to the wholesale dealer markets to establish contacts and now runs a successful business from her home and also door to door. She controls her own money and has also bought land in her own name. Faced with material deprivation where her in-laws did not give her enough to eat, she decided that she has to arrange for her own keep. Her husband was not directly violent but never protested against violence meted out by her in-laws. Now she interprets her husband's support as lack of interference in her activities. She owns title deeds of land, has financial investments in her name, and is the person approached by family members for any financial advice and help. Sarbani justifies single ownership and single or joint investments through the fact that her husband is illiterate and largely indifferent to the problems faced by the family. Despite being such a successful woman professionally, she mentions that her grandson will inherit all her property while she would marry off her grand-daughter to a suitable groom. Her own life of professional success does not 
translate into a desire to secure her grand-daughter's future through property or other investments.

Jhumpa Baidya started her business life by selling dry fish and tea packets door to door. She has now progressed to selling puffed rice and spices. Born into a well-off family, based on false information she was married to a poor man with a huge number of dependents. Faced with abject poverty and material deprivation in terms of food, medicines, and other necessities, she decided to start working despite resistance from her home. Even before she came in touch with Jeevika, she had a strong determination to change her life. She threatened her in-laws and husband with counter-violence if she was stopped from working. Interestingly, neighbors and roadside people with whom she had business dealings in the village came to her support. She was always praised for her ability to work hard, and since she spent for the welfare of the entire family, the dams of resistance gradually eroded. A woman who had actually threatened to "cut her mother-in-law into pieces" or to move to a separate house with her children if she was prevented from working, Jhumpa turns a complete somersault when she mentions at the end of the interview: "A woman can run a business when there is dire need, but the man has to do things like going to market to buy things for family. A woman should not do this. If a man does the things that a woman does, he is not a man, he will be counted a woman."

Bharati Bag and Pramita Halder both started their independent businesses after their husbands' deaths. While Bharati expanded the grocery shop owned by her deceased husband with the help of Swayamsampurna loans, Pramita started a fish business. Although the management of the shop is entirely in her own hands, Bharati seems to be dependent on the set of contacts developed by her deceased husband. She controls the finances but her adult son helps in market-related activities. She is also planning to start a new business for her son, with the help of people she knows, so that he can have independent work and earnings.

Pramita used to live in a rented apartment with her husband and children in the city of Kolkata. After her husband's death, she was brought back to her village by her brothers who feared that she would get into an amorous liaison and jeopardize the future of her children. Pramita started a fish business in her own area. She procures fish from a wholesale market near her village and sells them near her home. Although she admits that she can augment her sales if she moved further away to a bigger market, she feels that doing business near her home keeps her safe and enables her to garner her brothers' support in case of any difficulty. It is quite clear that she accepts sexual regulation as an inevitable and legitimate part of her life and pursues her business within these limits. If earlier her brothers had objected to her moving out, now her sons have assumed that role.

\section{Survivors of violence}

The story is markedly different for survivors of violence who live separate from their husbands. Perhaps the total breakdown of a marital state and the fact that they have nothing to lose anymore give them a confidence to question both the primacy of marriage or its trauma and the need to conform to ideals of motherhood or wifehood.

Sumita Ghosh and Priya Das, both survivors of violence who came to Alor Disha for support with their cases, started economic activities after being deserted by or separated from their husbands. While Sumita makes a meager income through selling paper packets and is unable to move out of the house because of the burden of care for her small children, Priya has forged out a different life for her own. Supported by her parents for further education and child care, she is in the last stages of nursing training and earns considerable income through her appointment at a cancer hospital in the city. She seems disinterested in the divorce and maintenance case and looks forward with zest to a new-found career.

Ranu Mondol and Lata Mazumdar, both activists with Alor Disha, were victims of domestic violence and live separate from their husbands. Economic activities and activism define their lives, and they seem to have found a new direction and meaning of life that enable them to politicize and overcome the initial trauma of their lives. Both agree that the material provision they received at their husband's home had a high physical and emotional cost, and that they are better off now in terms of independence, control, and peace.

\section{Women leaders}

Narratives of women in leadership positions within Swayamsampurna or the rights-based forums of Jeevika, irrespective of whether they are married or separated, mark a clear departure from other accounts. Besides working as a tailor, Madhumita Bag, a Swayamsampurna board member, also works as an insurance agent with two organizations. She got information about the insurance agent jobs through her network of associations in Swayamsampurna. Despite the fact that from her childhood she was technically equipped to earn and run her household, she was a lone warrior in negotiating domestic violence and managing family survival. Her position in Swayamsampurna has helped more in terms of resisting violence than creating income. Madhumita says: "Ever since Jeevika started holding meetings in my house and tried to first make my husband understand and later threaten him, he has stopped the physical battering. Even when he raises his hand 
now to slap me ... he stops midway." But the emotional violence continues. Her husband suspects her even now whenever she goes out for work and meetings, and she has to keep him informed all the time. Initially, neighbors had also slandered her when she went out for meetings or work. Now the same neighbors are scared of her because of her role and interventions in cases of violence in the village. There is an overall idea that Madhumita is powerful and should be left alone. However, Madhumita mentions that if the emotional torture stopped, she would be able to move about freely without the mental burden and this would help her even further in augmenting her income.

While some women use threats and open resistance, based on organizational support, others use subversive tactics to negotiate violence at home. Sipra Biswas, a loan officer, mentions that she uses alternative tactics for justifying her work outside home. Owing to her husband's erratic and insufficient income, she stressed the need for a stable income to legitimize her job. When her husband became violent, incited by the comments of other family members and neighbors, she convinced him that those people were jealous of the economic wellbeing brought about by a double income. To appease the family members, Sipra lamented the failure of her husband to be a sufficient provider and said that she did not have the luxury of sitting at home.

Even now, Sipra has to face continuous surveillance by her husband and make legitimate excuses for any delays in her regular office timings. Raised by a single mother, Sipra had always felt that she lacked support in case she went against the wishes of her husband. Jeevika has emerged as a platform that gives her this support. Sipra's motivation to join Jeevika, much before she became a loan officer with Swayamsampurna, stemmed from the desire to step out of the house. Even now the job means much more than income to her. However, she carefully hides these dimensions of her life from her husband and in-laws. She also makes financial investments without the knowledge of her husband and places her professional engagements in the framework of family wellbeing and income. Sipra further mentions that the constant nagging and suspicion by her husband had initially affected her work performance, and that she would often make mistakes in calculations, fatal in her job as a loan officer. However, by means of her association and exposure through Jeevika, she has learned to deal with these issues intelligently and become less emotionally affected by such issues.

There are many more instances of women making voluntary savings, fixed deposits, or earning incomes without the knowledge of their husbands. Sometimes this is motivated by the fact that husbands would then stop contributing to the
Economic independence helps but more important is the ideological apparatus or the existence of a human support network that can support women's attempts to rupture violations of rights and physical integrity.

household, sometimes by the fact that husbands would wrest control over the finances, and sometimes simply by a sense of securing one's future or the future of one's children independently.

\section{From domestic chores to rights and joint management}

Interestingly, in none of the accounts is there any stark evidence of a reorganization of reproductive responsibilities. Most women engage in economically gainful activities after completing their required domestic chores at home. Sometimes however, husbands or children come forward to assist in cooking and other activities in cases of joint business or selfbusiness once it has been established that the whole family gains economically from such activities.

In a case such as Sipra Biswas, the household gives her work schedule preference on weekdays because she has a timebound regular job. On weekends, however, no such cooperation is available and she has to make up for her absence on weekdays. A large part of this minimal cooperation has been hard-earned and is as much related to the life cycle of women as to the success of their economic ventures. Most women respondents, with few exceptions, were married at an early age (between 14 and 17 years) and are now in their forties with grown-up children. Their initial journey through business, singly or jointly, has been riddled with hurdles, mostly in terms of restrictions on mobility on the ground of sexual control. It is only after years of establishing credibility and legitimacy through their investment in family welfare that such women have been able to earn a measure of cooperation and control.

Women not directly associated with Jeevika's rights-based programs do not echo the same attachment to the organization or articulate the same language of rights. However, all of them seem aware of the existence of such programs. Many survivors of violence came in touch with Jeevika through information given out by ordinary members. The authors' own experience of working with members over several years show a marked difference in responses during one-day or three-day training events, discussing gender rights and entrepreneurship. From a situation in which women found it impossible to articulate that they can have a role in major family decisions or found it a matter of shame that they were the principal breadwinners, some change has inevitably been wrought. 
Whether or not situations have actually changed for a large section of women on the ground cannot be ascertained through these few interviews. However, the authors' experience of working with groups and the interviews themselves are proof that women can find a new political language of rights. Perhaps they are still hesitant to admit to the failure of the male provider model or assert that they can and do take decisions at home, but the language of "joint decision making" and "joint management" have entered the vocabulary. This by itself is a harbinger of change. In the absence of concrete alternatives for emotional, economic, and social support, marriage continues to define identities and security. Only in extreme cases of violation of rights and physical integrity, do marriages break down. However, many women negotiate the multiple deprivations and indignity, sometimes through manipulation, sometimes through conformity, and sometimes through open challenge. Economic independence helps, but more important is the ideological apparatus or the existence of a human support network that can support these attempts at ruptures.

\section{Concluding discussion}

Jeevika's journey began with a focus on meeting practical needs of women by enabling the flow of money into women's hands and that could be used for a variety of purposes, ranging from consumption to production. A number of development organizations as well as women's groups have tread on this path since the 1990s. What perhaps marks Jeevika apart is its integration of a rights-based approach into the microfinance program and its successful effort in developing leadership from within the community. Not only leaders, but also community members related to Jeevika simply through the savings and loan cycle are aware of the multifarious activities and programs Jeevika undertakes. Even if they do not identify these as necessary or relevant for their lives, it creates a window through which information and ideas seep in and which can be used as reference by other women in distress. Most women who have emerged as leaders have one thing in common: They were excited more by the prospect of stepping out and engaging in Jeevika's rights-based activities rather than by income generation, loans, or savings alone. Sometimes this was prompted by extreme forms of violence, sometimes by a childhood desire to explore life that had been stifled through years of wifehood and motherhood. Their association with Jeevika has given them recognition and self-esteem that money alone could not bestow, and it is on the basis of these that they are able to challenge, fight, or negotiate much of the patriarchal dominance in their lives. For women associated with production, loans have helped, and perhaps it is not a matter of coincidence that they seem equally aware of the financial rules
Perhaps the main contribution of Jeevika is to provide a support network of people, resources, and income generation that pushes for a redefinition of what is possible or impossible for women to achieve or to enable them to imagine a life beyond motherhood and wifehood. Not many are ready to take this up. But the few who do have a place to go.

of Jeevika as well as the financial negotiations of their own or family business.

\section{Revisioning lives}

All respondents agree that Jeevika has meant a certain measure of independence and opportunity and seem aware of the transfer of ownership from Jeevika to Swayamsampurna. Some women other than leaders have also been part of training programs and been able to justify overnight stays by citing organizational demands. Jeevika, in a way, has given them a reasonable excuse to step out and to spend some time free of regular bondage. The leaders have moved a step further and converted this to a revisioning of their lives in which they are able to consider single lives with satisfaction or strategize within marital homes to snatch a share of their freedom. This perhaps is the potential Jeevika has attempted to create for a movement toward meeting strategic gender needs. No single organization can create a radical change when relations of gender and economic opportunities available to women are deeply entrenched in a patriarchal society. But Jeevika does offer a platform of support, both ideological and material, for those who want to take the plunge and defy such norms.

It is interesting to note that while economically successful women who are also in control of finances continue to rely on benevolent and cooperative families or echo the logic of family welfare to justify their entrepreneurship, it is the leaders who push back the limits of what is considered legitimate for a woman to do and to be. Many women who earn and control incomes have been able to make this journey because of the breakdown of the male provider model or because of the absence of a benevolent patriarch. In fact, in the undercurrents of their narrative one can discern a tone of lament that they did not have the opportunity to live typical lives of dependence and care. It is rather in the voices of the leaders that we see any significant challenge to such notions of dependence. Many such women, even if they continue traditional roles in their family, do it with an awareness of an asymmetry of gendered roles. Sometimes, preserving the general framework of traditional roles is a strategy to ensure an unquestioned continuation of their association with the organization. But their articulation shows great clarity of thought in discerning the difference in situations at home and the organization. 
Although association with Jeevika or association with incomegenerating activities have led to abatement of open violence or even given them a measure of control and increased decisionmaking, they are aware of double roles and double lives played out on an everyday basis. They seem aware that while the position and dignity in Jeevika derives from their work and commitment, at home position and dignity depends on their ability to discharge the traditional duties of wife and mother. However, the presence of Jeevika helps, not only in the abatement of violence but also in giving them an identity which is built on their contribution as an activist and worker.

It is in this context perhaps that Jeevika has been able to facilitate a change in the ideological frame of gender relations at home. Some of the leaders mention that they continuously speak to their sons, daughters, and daughters-in-law about the ideas they gain through Jeevika so that they are able to carve out a life different from their own. For most such women, who are less educated and married young, and who lived violent lives during early years of marriage, Jeevika promises more than loans. One survivor of violence, who is yet to emerge from her trauma, mentions that although her case did not go much forward despite help from Alor Disha, she has made valuable friends in the group. She talks about her "friends" in Alor Disha whose houses she frequents whenever depression and pain eat away at her and when the slandering in her neighborhood goes beyond tolerance. Perhaps the main contribution of Jeevika therefore is to provide a support network of people, resources, and income generation that pushes for a redefinition of what is possible or impossible for women to achieve or to enable them to imagine a life beyond motherhood and wifehood. Not many are ready to take this up. But the few who do have a place to go.

\section{Notes}

1. See, e.g., Banerjee (1997); Standing (1999); Chandrasekhar and Ghosh (2002); Mukherjee (2004); Patnaik (2006).

2. See John (1996); Sengupta (2013).

3. Brym, et al., (2005); Sengupta (2013).

4. Kabeer (2005).

5. Hashemi, Schuler, and Riley (1996); Goetz and Sengupta (1996); Hulme and Mosley (1996); Rogaly (1996); Khandker (2005); Armendariz and Morduch (2007); Cull, Kunt, and Morduch (2008).

6. A Block is an area-based unit of administrative governance. Each state, say, West Bengal, is divided into several Districts. Each District, say, South 24 Parganas, is divided into several Blocks, each of which has several villages under its purview. At the village level, the governing body is the Panchayat. The government appoints several people at the Block level to look into the welfare and development of villages in that Block. It is supervised by the Block Development Officer.

7. For a detailed description of women and development, including efficiency and equity approaches, see Moser (1989). Quote: Moser (1989, p. 1813).

8. One scholar argues: Buvinic (1983). Bangladeshi study: Rahman (1999). Urban microfinance in Delhi: Jitha (2013). Feminization of poverty studies: Cagatay (1998); Chant (2006).

9. Swayamsampurna lends to its members at a rate of, say, 2 percent per month (the monthly interest to be paid decreases with the gradual repayment of principal loan amount) and also charges a processing fee of 1 percent of the total loan amount discharged. A part of the interest income is used to repay with interest the loans Swayamsampurna has taken from banks and other organizations for on-lending. The remaining interest income and processing fee covers operational costs including salary to loan officers and stipends to board members.

10. One author writes: Mosedale (2005).

11. The (im)possible: Hayward (1998). Quote: Mosedale (2005, p. 252).

12. To protect their identities, the names of all respondents have been changed.

13. Direct interview quotes are left with the original spelling.

\section{References}

Armendariz, B. and J. Morduch. 2007. The Economics of Microfinance. Cambridge, MA: MIT.

Banerjee, N. 1997. "How Real is the Bogey of Feminization?" The Indian Journal of Labour Economics. Vol. 40, No. 3, pp. 427-438.

Brym, R.J., S. Chung, S. Dulmage, C. Farahat, M. Greenberg, and M. Ho. 2005. "In Faint Praise of the World Bank's Gender Development Policy." Canadian Journal of Sociology. Vol. 30, No. 1, pp. 95-111. http://dx.doi.org/10.2307/4146159

Buvinic, M. 1983. Women's Issues in Third World Poverty: A Policy Analysis. Women and Poverty in the Third World. John Hopkins University Press, Baltimore, MD.

Cagatay, N. 1998. "Gender and Poverty.” Working Paper No. 5. United Nations Development Programme.

Chandrasekhar, C.P. and J. Ghosh. 2002. The Market That Failed: Neoliberal Economic Reforms in India. Left Word Books, New Delhi.

Chant, S.H. 2006. "Re-thinking the 'Feminization of Poverty' in Relation to Aggregate Gender Indices." Journal of Human Development. Vol. 7, No. 2, pp. 201-220. http://dx.doi.org/10.1080/14649880600768538

Cull, R., A.D. Kunt, and J. Morduch. 2008. "Microfinance Meets the Market. The Financial Access Initiative." Retrieved from http://www-wds.worldbank.org [accessed on 20 December 2010].

Goetz, A.M. and R. Sengupta. 1996. "Who takes the Credit? Gender, Power and Control over Loan Use in Rural Credit Programs in Bangladesh." World Development. Vol. 24, No. 1, pp. 45-63. 
http://dx.doi.org/10.1016/0305-750X(95)00124-U

Hashemi, S.M., R.S. Schuler, and A.P. Riley. 1996. "Rural Credit Programs and Women's Empowerment in Bangladesh." World Development. Vol. 24, No. 4, pp. 635-653.

http://dx.doi.org/10.1016/0305-750X(95)00159-A

Hayward, C.R. 1998. "De-facing Power." Polity. Vol. 31, pp. 22-34.

http://dx.doi.org/10.2307/3235365

Hulme, D. and P. Mosley. 1996. Finance Against Poverty. London: Routledge.

Jitha, T.J. 2013. "Mediating Production, Re-powering Patriarchy: The Case of Micro Credit." Indian Journal of Gender Studies. Vol. 20, No. 2, pp. .253-278.

John, M.E. 1996. "Gender and Development in India, 1970s-1990s: Some Reflections on the Constitutive Rroles of Contexts." Economic and Political Weekly. Vol. 31, No. 47, pp. 3071-3077.

Kabeer, N. 2005. "Is Microfinance a Magic Bullet for Women's Empowerment? Analysis of Findings from South Asia." Economic and Political Weekly. Vol. 40, No.s 44 \& 45, pp. 4709-4718.

Khandker, S.R. 2005. "Microfinance and Poverty: Evidence Using Panel Data from Bangladesh." The World Bank Economic Review. Vol. 19, No. 2, pp. 263-286.

http://dx.doi.org/10.1093/wber/lhi008

Mosedale, S. 2005. "Policy Arena. Assessing Women's Empowerment: Towards a Conceptual Framework." Journal of International Development. Vol. 17, pp. 243-257. http://dx.doi.org/10.1002/jid.1212

Moser, C.O.N. 1989. "Gender Planning in the Third World: Meeting Practical and Strategic Gender Needs." World Development. Vol. 17, No. 11, pp. 1799-1825. http://dx.doi.org/10.1016/0305-750X(89)90201-5

Mukherjee, M. 2004. "Women and Work in the Shadow of Globalization.” Indian Journal of Gender Studies. Vol. 11, No. 3, pp. 275-290. http://dx.doi.org/10.1177/097152150401100302

Patnaik, P. 2006. "The Meaning of Contemporary Globalization," in M.E. John, P.K. Jha, and S.S. Jodhka, eds. Contested Transformations: Changing Economies and Identities in Contemporary India. Tulika Books: New Delhi.

Rahman, A. 1999. "Micro-credit Initiatives for Equitable and Sustainable Development: Who Pays?" World Development. Vol. 27, No. 1, pp. 67-82. http://dx.doi.org/10.1016/S0305-750X(98)00105-3

Rogaly, B. 1996. "Micro-finance Evangelism, "Destitute Women,", and the Hard Selling of a New Anti-poverty Formula." Development in Practice. Vol. 6, No. 2, pp. 100-112.

http://dx.doi.org/10.1080/0961452961000157654

Sengupta, N. 2013. "Poor Women's Empowerment: The Discursive Space of Microfinance." Indian Journal of Gender Studies. Vol. 20, No. 2, pp. 279-304. http://dx.doi.org/10.1177/0971521513482220

Standing, G. 1999. “Global Feminization through Flexible Labor: A Theme Revisited.” World Development. Vol. 27, No. 3, pp. 583-602.

http://dx.doi.org/10.1016/S0305-750X(98)00151-X 